\title{
Storm-driven across-shelf oceanic flows into coastal waters
}

\author{
Sam Jones ${ }^{1}$, Mark Inall ${ }^{1,2}$, Marie Porter ${ }^{1}$, Jennifer A. Graham ${ }^{3}$, and Finlo Cottier ${ }^{3,4}$ \\ ${ }^{1}$ Scottish Association for Marine Science, Oban, Argyll, PA371QA, UK \\ ${ }^{2}$ University of Edinburgh, School of Geosciences, Edinburgh, EH93FE, UK \\ ${ }^{3}$ Centre for Environment, Fisheries and Aquaculture Science, Pakefield Road, Lowestoft, NR330HT, UK \\ ${ }^{4}$ Faculty of Biosciences, Fisheries and Economics, UiT The Arctic University of Norway, Troms $\varnothing$, Norway
}

Correspondence: Sam Jones (sam.jones@sams.ac.uk)

Received: 17 October 2019 - Discussion started: 30 October 2019

Revised: 6 February 2020 - Accepted: 24 February 2020 - Published: 2 April 2020

\begin{abstract}
The North Atlantic Ocean and northwest European shelf experience intense low-pressure systems during the winter months. The effect of strong winds on shelf circulation and water properties is poorly understood as observations during these episodes are rare, and key flow pathways have been poorly resolved by models up to now. We compare the behaviour of a cross-shelf current in a quiescent period in late summer, with the same current sampled during a stormy period in midwinter, using drogued drifters. Concurrently, high-resolution time series of current speed and salinity from a coastal mooring are analysed. A Lagrangian analysis of modelled particle tracks is used to supplement the observations. Current speeds at $70 \mathrm{~m}$ during the summer transit are $10-20 \mathrm{~cm} \mathrm{~s}^{-1}$, whereas on-shelf flow reaches $60 \mathrm{~cm} \mathrm{~s}^{-1}$ during the winter storm. The onset of high across-shelf flow is identified in the coastal mooring time series, both as an increase in coastal current speed and as an abrupt increase in salinity from 34.50 to 34.85 , which lags the current by $8 \mathrm{~d}$. We interpret this as the wind-driven advection of outer-shelf (near-oceanic) water towards the coastline, which represents a significant change from the coastal water pathways which typically feed the inner shelf. The modelled particle analysis supports this interpretation: particles which terminate in coastal waters are recruited locally during the late summer, but recruitment switches to the outer shelf during the winter storm. We estimate that during intense storm periods, onshelf transport may be up to $0.48 \mathrm{~Sv}$, but this is near the upper limit of transport based on the multi-year time series of coastal current and salinity. The likelihood of storms capable of producing these effects is much higher during positive North Atlantic Oscillation (NAO) winters.
\end{abstract}

\section{Introduction}

The shelf seas and abyssal ocean are often treated as separate systems as they exhibit very different behaviours despite the lack of a physical barrier between the two. The shallow continental shelves are responsible for roughly $25 \%$ of global primary production (Simpson and Sharples, 2012) and play host to the vast majority of human-ocean interactions. The exchange of water between the ocean and shelf seas is still an evolving field of study, as is our understanding of how oceanic and shelf-edge processes play out at the coast (Brooks and Townsend, 1989; Holt et al., 2009; Huthnance et al., 2009; Münchow and Garvine, 1993). In this paper we investigate the behaviour of a newly characterised across-shelf current, the Atlantic Inflow Current (AIC; Porter et al., 2018), and the role it plays in transporting oceanic water across the northwest European shelf.

The northwest European shelf is bounded to the west by the northeastern Atlantic and Rockall Trough basins (Fig. 1a). A topographically steered slope current flows along the shelf edge between Biscay and Norway, becoming increasingly consistent in flow speed and direction north of the Celtic Sea. The stability and persistence of the slope current, particularly north of $55^{\circ} \mathrm{N}$, favour along-slope (poleward) transport and inhibit ocean-shelf exchange (Huthnance et al., 2009; Pingree et al., 1999; White and Bowyer, 1997). Despite the reduced cross-shelf flow associated with the slope current, the presence of relatively undiluted oceanic water is detectable many tens of kilometres on-shelf (Inall et al., 2009; Jones et al., 2018; Jones, 2016) at several persistent locations along the shelf. These regions of oceanic incursion are important for the delivery of production-limiting oceanic 

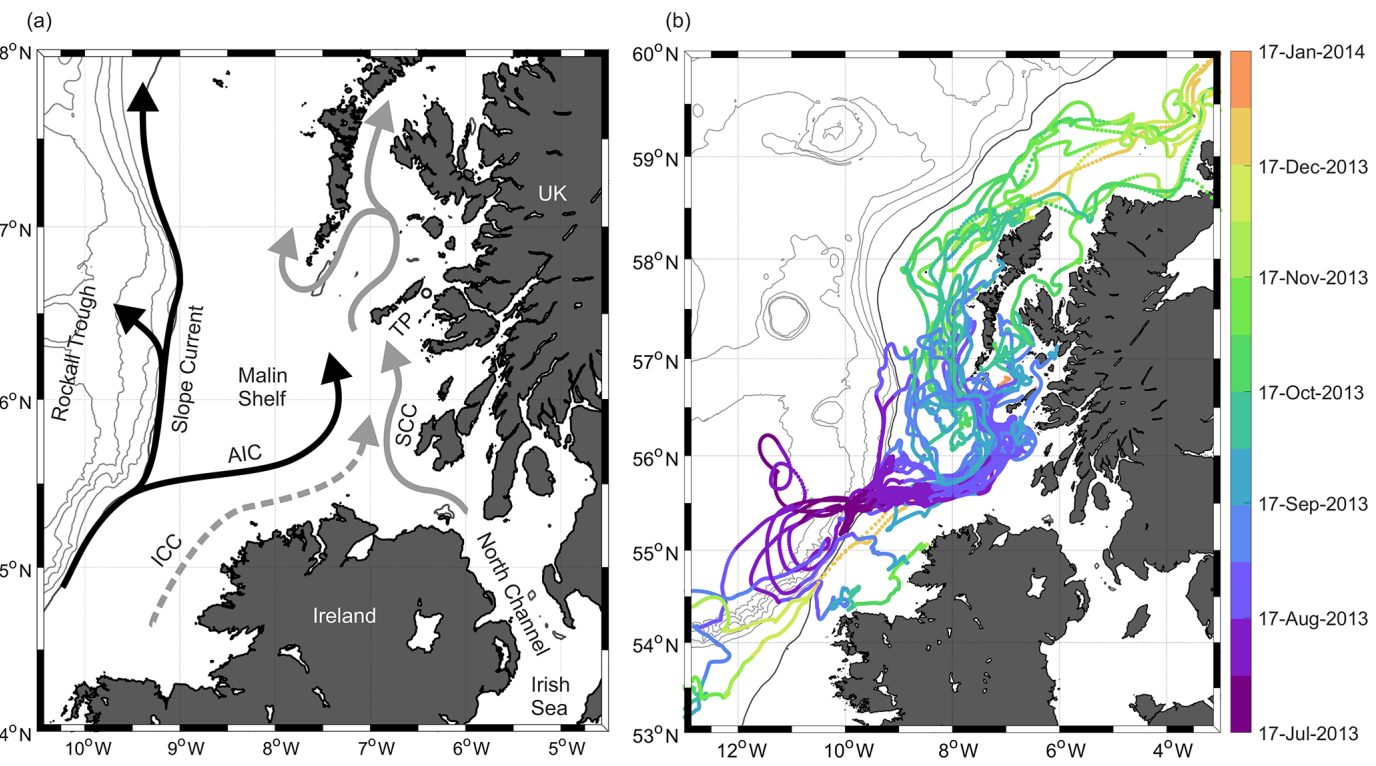

Figure 1. (a) Schematic of study regions showing the features mentioned in text. Oceanic water pathways are shown in black, and coastal water pathways are shown in grey. The solid grey line shows the Scottish Coastal Current (SCC), and the dashed grey line indicates the pathway of the Irish Coastal Current (ICC, summer only). AIC: Atlantic Inflow Current, TP: Tiree Passage. The location of the Tiree Passage Mooring is indicated by the black circle. (b) Trajectories of drifters released during the FASTNEt JC88 cruise (drogued at 15 and $70 \mathrm{~m}$ ), coloured by date. Bathymetry contours from GEBCO bathymetry (http://www.gebco.net/, last access: 24 July 2017). GEBCO: General Bathymetry Chart of the Oceans.

nutrients to coastal seas (Painter et al., 2016) and, by extension, the level of primary production and prospects of local fisheries (Gowen et al., 1998; Miller, 2013; Proctor et al., 2003). The waters of the northwest European shelf exhibit a general clockwise circulation around the UK, and if oceanic water remains on the shelf it will ultimately be mixed into this coastal current system (Hill, 1983; Simpson and Hill, 1986). Thus, these oceanic incursions have the potential to influence not only local coastal seas, but also those downstream, for example the North Sea. This on-shelf transport implies a balancing off-shelf flow of water, and the properties of the North Atlantic Current are gradually modified as it progresses polewards through its interaction with shelf seas (Holliday et al., 2000; Reid et al., 2001)

While schematics of shelf circulation typically infer a permanent residency of oceanic water on regions of the shelf (Ellett and Edwards, 1983; Ellett and MacDougal, 1985; Inall et al., 2009; Simpson et al., 1979), in reality these intrusions appear to be sporadic both in duration and geographic extent. Evidence for the spatial mobility of fronts and water masses on the Malin Shelf is provided by satellite observations, as well as in situ cruise and mooring data (Ellett and Edwards, 1983; Inall et al., 2009; Jones et al., 2018; Jones, 2016; Porter et al., 2018). The variable occupation of the Malin Shelf by oceanic water means that coastal water properties in some regions exhibit high temporal variability (Jones et al., 2018). We seek to characterise the causes and nature of these oceanic intrusions.
Our investigation builds on findings from a drifter release on the Malin Shelf during the FASTNEt shelf-edge observation campaign (Porter et al., 2018, Fig. 1b). Drogued drifters released into the slope current in July 2013 moved on-shelf downstream of a canyon system at $55.5^{\circ} \mathrm{N}$ and travelled towards the coast in a coherent current which the authors named the AIC. While on-shelf flow is captured by models of the region (Aleynik et al., 2016; Graham et al., 2018b; Holt et al., 2009; O'Dea et al., 2012; Xing and Davies, 2001; Young and Holt, 2007) and previous drifter studies have provided insight on local circulation (Booth, 1988; Burrows and Thorpe, 1999; Pingree et al., 1999), this study provided the first evidence of a narrow, jet-like current crossing $f / h$ contours and transporting oceanic water onto the adjacent shelf.

We also utilise salinity and current observations from a fixed mooring in Tiree Passage off the west coast of Scotland. The Tiree Passage Mooring (TPM) tracks the highly variable mix of coastal water, freshwater runoff, and oceanic water that flows through the Inner Hebrides, collectively referred to as the Scottish Coastal Current (SCC). The SCC originates in the baroclinically driven outflow from the Irish Sea (Hill, 1987; Hill and Simpson, 1988; Jones, 2016) and receives contributions from rivers and sea lochs, causing it to become less saline and increase in volume as it progresses northward. Residual currents at the TPM are typically poleward with an average speed of $10 \mathrm{~cm} \mathrm{~s}^{-1}$ though with much variability at timescales between a few hours and several weeks (Inall et al., 2009). The salinity measured by the TPM is highly vari- 


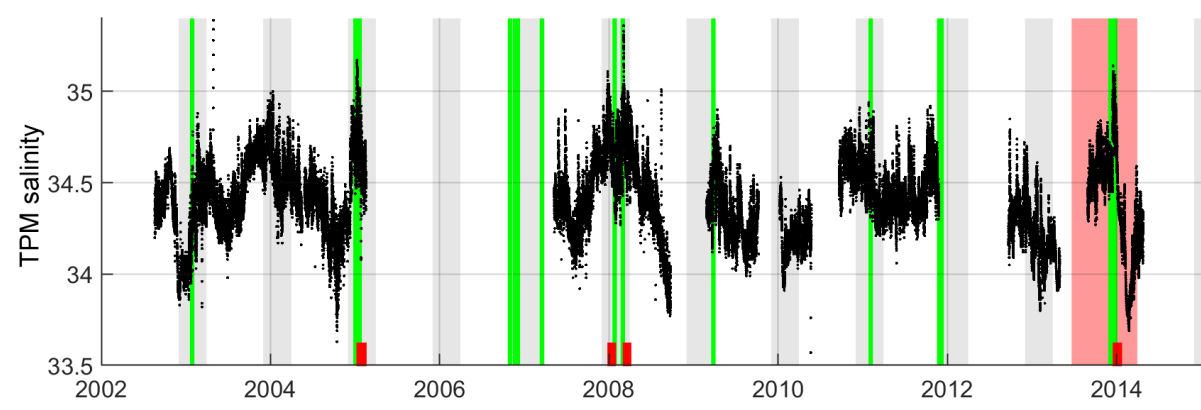

Figure 2. Salinity at the Tiree Passage Mooring at $20 \mathrm{~m}$. Grey bars denote winter months (DJFM). Green lines show instances of daily mean westerly winds on Malin Shelf exceeding $18 \mathrm{~m} \mathrm{~s}^{-1}$ after Jones et al. (2018); there are 17 occurrences between 2002 and 2015 . Red ticks indicate high-salinity pulses (HSPs). The pink bar highlights the drifter study period (shown again in Fig. 5).

able on inter-annual timescales but sometimes also features abrupt changes over a few hours or days (Fig. 2). Salinity has proved to be a sensitive tracer of water masses on the northwest European shelf and was found by Jones et al. (2018) to track the relative positions and concentrations of oceanic $(S>35.2)$ and coastal $(S<34.9)$ water masses on the shelf. The main mode of variability in salinity was found by the authors to be due to a wind control mechanism on the origin of the SCC such that sustained easterly winds enhanced outflow from the Irish Sea, whereas sustained westerly winds retarded it. This work built on earlier observations of wind control on the North Channel of the Irish Sea (Bowden and Hughes, 1961; Brown and Gmitrowicz, 1995), observations of temperature and current speed in Tiree Passage (Inall et al., 2009), and model studies indicating that wind control of current pathways may extend to the wider northwest European shelf (Davies and Xing, 2003; Xing and Davies, 2001).

Once or twice during most winters a brief pulse of very high-salinity water is observed at the TPM, and these highsalinity pulses (HSPs) are often associated with storm events (Jones et al., 2018). An HSP constitutes a brief but significant change from usual circulation patterns because nearly undiluted oceanic water is observed at a coastline normally buffered from the Atlantic by the SCC. HSPs may be an important mediator of winter coastal water properties as oceanic water is a source of both heat and nutrients to the shelf seas (Painter et al., 2016; Porter et al., 2018; Siemering et al., 2016). They may have other impacts at the coast, for instance the import of organisms typically restricted to waters further offshore.

Understanding of the drivers of these events is scant: while HSPs are associated with storm activity, salinity at the TPM does not correlate simply with wind forcing on the shelf (Jones et al., 2018). Also, it is not known whether accepted transport pathways from the outer shelf hold true when wind and wave action mask the weaker baroclinic flows which prevail during quiescent periods. Observations of HSPs are few as they typically occur in midwinter when most satellite sensors are obscured by cloud. In addition, they are associated with stormy periods in a region notorious for rough seas, so they are generally not captured by oceanographic cruises which cannot sample in such conditions.

This study capitalises on the fortuitous recirculation of two drifters out of the 30 released in July 2013 during the FASTNEt programme (Porter et al., 2018). While most drifters had exited the Malin Shelf by October 2013, two drifters drogued at $70 \mathrm{~m}$ were captured by an eddy in the Rockall Trough shortly after release and only crossed onto the Malin Shelf in December 2013. This transit coincided with an HSP being measured by the TPM, so it has the potential to explain the origin and nature of these phenomena. We therefore examine the Lagrangian properties of the December drifter tracks in comparison with the fixed time series at the TPM. In addition, we compare the shelf conditions during this winter shelf transit with the late summer conditions sampled by the first cluster of drifters. This suite of observations is complemented by a modelled particle-tracking experiment.

\section{Methods}

\subsection{Drogued drifter release}

On 17 July 2013, 30 satellite-tracked GPS drifters were released from the RRS James Cook on the $600 \mathrm{~m}$ contour at $55.2^{\circ} \mathrm{N}$. The drifters were MetOcean SVP (Surface Velocity Program) drifting buoys fitted with a holey-sock drogue (Sybrandy et al., 2009). Within this release, 15 of the drifters were drogued to track water at $15 \mathrm{~m}$ of depth in the mixed layer, and 15 were drogued at $70 \mathrm{~m}$ to track water at the bottom of the seasonal pycnocline. The drifters were fitted with a strain gauge which enabled checks for grounding, snagging, and drogue loss to be performed. Instances of unusual drifter displacement due to vessel interference were also identified and subsequent observations rejected. For further information on the quality control of drifter data, see Porter et al. (2018).

The drifters were configured to report GPS positions every $3 \mathrm{~h}$. To exclude high-frequency motions such as tides and inertial oscillations from the drifter tracks, the data were fil- 
tered with a 10th-order zero-phase Butterworth low-pass filter with a cut-off at $2 \mathrm{cpd}$ (cpd: cycles per day). There were numerous instances of a single missing GPS position, but longer gaps were rare, with a maximum gap size of $20 \mathrm{~h}$. In all cases, positional data gaps were linearly interpolated. Drifter velocities were calculated using displacements from the filtered location data.

\subsection{Tiree Passage Mooring (TPM)}

The TPM is situated in northern Tiree Passage at $56.6^{\circ} \mathrm{N}$, $6.4^{\circ} \mathrm{W}$ in water $45 \mathrm{~m}$ deep. Hourly current and temperature data were collected at the mooring using Aanderaa current meters between 1981 and 2014 at a nominal depth of $20 \mathrm{~m}$. Reliable salinity measurements commenced in 2002 with the addition of a Sea-Bird Microcat to the standard array. The mooring was serviced at 3-5-month intervals by staff at the Scottish Association for Marine Science (SAMS), Oban, though many gaps exist in the time series due to the challenging conditions often found in Tiree Passage. Conductivitytemperature-depth (CTD) casts were conducted at the beginning and end of most mooring deployments to aid calibration of the fixed instruments. For more information on the calibration and quality control of the TPM dataset, see Jones et al. (2018).

\subsection{ECMWF forecast reanalysis data}

Daily $10 \mathrm{~m}$ wind and sea level pressure data from the ERA-Interim $0.75^{\circ} \times 0.75^{\circ}$ product were obtained from the European Centre for Medium-Range Weather Forecasts (ECMWF; Dee et al., 2011). The ERA-Interim product was chosen over the more recent ERA5 release as the former was used to force the model used in this study.

\subsection{AMM15 model data}

This study uses model output from AMM15 (Atlantic Margin Model, $1.5 \mathrm{~km}$ resolution), which was developed and validated by Graham et al. (2018a, b) through the UK Joint Weather and Climate Research Programme. This incarnation of the model builds on AMM7 (7 km resolution), which has been utilised and validated by numerous studies (O'Dea et al., 2017, 2012). Both models are based on NEMO (Nucleus for European Modelling of the Ocean) architecture.

AMM15 bathymetry is derived from EMODnet (EMODnet Portal, September 2015 release), and it uses a $z *-\sigma$ coordinate system (Siddorn and Furner, 2013) with 51 vertical levels. This hybrid system utilises terrain-following coordinates fitted to a smoothed envelope bathymetry. Vertical turbulent viscosity and diffusivity are calculated using the generic length scale scheme (Umlauf and Burchard, 2003). For lateral diffusion, only minimal eddy viscosity is applied because the horizontal resolution in AMM15 resolves the internal Rossby radius on the shelf. A bi-Laplacian diffusion scheme is used along model levels for both momentum and tracers, with coefficients of $6 \times 10^{7}$ and $1 \times 10^{5} \mathrm{~m}^{4} \mathrm{~s}^{-1}$, respectively. For more information on the core model configurations, see Graham et al. (2018a). The data used in this study are extracted from the same hindcast simulation presented in Graham et al. (2018b) and cover the period AugustDecember 2013.

\subsection{Modelled particle-tracking study}

To test the implication of the observed drifter trajectories, we conducted a series of offline particle-tracking experiments using AMM15-modelled velocities, with daily mean fulldepth U/V velocities obtained from a hindcast for the period of interest. From this dataset, horizontal velocities at 20 and $70 \mathrm{~m}$ depths were extracted to coincide with the TPM and drifter observation depths. We contrasted two periods sampled by the drifters: 1 to 11 August and 15 to 25 December 2013. In each case, the $10 \mathrm{~d}$ interval was deemed an "observation period". Particles were released at daily intervals across the local model domain for the $40 \mathrm{~d}$ preceding the observation period and during the $10 \mathrm{~d}$ observation period (Fig. 3). Particles which were advected into the observation polygons during the observation period were identified and their release location noted. The experiment was repeated five times to sample a range of diffusive random walks, resulting in a total of 250 unique particles being released from each location in Fig. 3a. Our analyses focus on the origin of the particles which reached the observation polygons on the inner shelf.

The particles were tracked using a 2D Lagrangian scheme. The 2D location of a particle $X_{p}^{t}(x y)$ at time $t$ is calculated using

$X_{p}^{t}(x, y)=X_{p}^{t-\Delta t}(x, y)+\Delta t U_{p}(x, y)+\partial_{H}$,

where $\Delta t$ is the time step of the offline AMM15 model output $(1 \mathrm{~d}), U_{p}(x, y)$ is the $2 \mathrm{D}$ model velocity at the particle location obtained using bilinear interpolation, and $\partial_{H}$ is a random walk diffusive component (following Gillibrand and Willis, 2007, and van Sebille et al., 2018):

$\partial_{H}(x, y)=\gamma\left[6 . K_{\mathrm{H}} \cdot \Delta t\right]^{1 / 2}$,

where $\gamma$ is a real random number $(\gamma \in[-1,1])$ and $K_{\mathrm{H}}$ is the horizontal eddy diffusivity. For the $1.5 \mathrm{~km}$ model grid of AMM15, a diffusivity of $1 \mathrm{~m}^{2} \mathrm{~s}^{-1}$ was chosen to reflect the low lateral momentum diffusion used in the model physics. We reran the experiment with horizontal eddy diffusivity values between 0.5 and $3 \mathrm{~m}^{2} \mathrm{~s}^{-1}$ and found that the results were robust with respect to this coefficient.

\section{Results}

\subsection{Drifter study}

In this study only the on-shelf portions of drifter tracks (depth $<200 \mathrm{~m}$ ) are investigated; for a detailed analysis of 
(a)

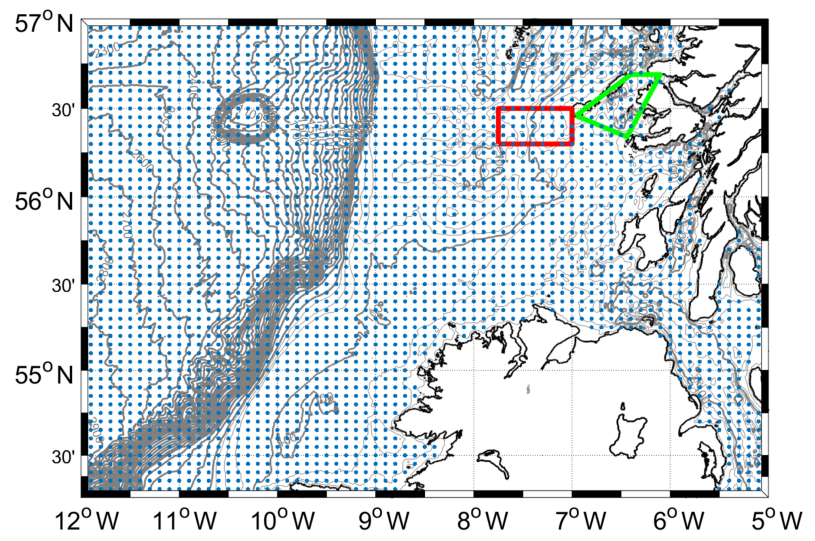

(b)

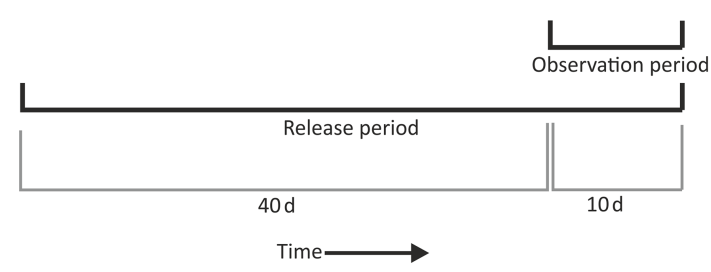

Figure 3. (a) Map of particle release locations, shown by blue points. The green polygon shows the observation region for $20 \mathrm{~m}$ particles; the red polygon shows the observation region for $70 \mathrm{~m}$ particles. (b) Schematic showing the observation period preceded by $40 \mathrm{~d}$ of particle releases. Bathymetry contours from EMODnet bathymetry (https://www.emodnet-bathymetry.eu/, last access: September 2015).

shelf-edge dynamics from the drifter observations, see Porter et al. (2018). In addition, we use only tracks from drifters drogued at $70 \mathrm{~m}$ as those drogued at $15 \mathrm{~m}$ all moved on-shelf in August 2013, thus precluding an autumn-winter comparison. The drifters were initially released into the slope current but diverged at the canyon system at $55.5^{\circ} \mathrm{N}$, with some moving offshore and being advected southwards for a time before crossing the shelf edge and others moving onshelf north of the release point. The periods of drifter transit of the Malin Shelf can be split into two groups: the first group crossed the shelf edge in August and September 2013, whereas the second group initially recirculated in deep water before moving on-shelf in mid-December 2013. Shallow bathymetry prevents the $70 \mathrm{~m}$ drifters from passing through Tiree Passage, but as flow on the outer Malin Shelf is close to barotropic in December (Davies and Xing, 2003; Ellett and Edwards, 1983; Jones et al., 2018), we consider these results to be somewhat representative of near-surface currents.

Cross-shelf drifter progress in the complex Malin Shelf region is dependent on local bathymetry and the location at which each drifter crossed the shelf edge. However, drifters from both groups were advected eastwards in the AIC and passed through the same region north of Ireland, so the time taken to reach this point from the shelf edge provides a metric of cross-shelf progress (Fig. 4). Beyond this point the tracks turn northward and scatter, and inter-comparison of drifters is once again problematic. Consequently, we chose a meridional line at $8^{\circ} \mathrm{W}$ (roughly mid-shelf) to define drifters as having reached the inner shelf and, by implication, being on a track which passes near or terminates at the Scottish coastline.

Seven drifters travelled between the shelf edge and $8^{\circ} \mathrm{W}$ in the AIC during August-September 2018, and two drifters transited this route in December 2013. A visual comparison of tracks in Fig. 4 shows that drifter speeds were typically between 10 and $20 \mathrm{~cm} \mathrm{~s}^{-1}$ in group 1 (August 2013). One of the drifters in Fig. 4a briefly crossed the shaded region delineating the $70 \mathrm{~m}$ bathymetry without any indication of seabed interference in its strain gauge; we speculate that there may be errors in the bathymetry in this region.

Flow at $70 \mathrm{~m}$ was generally on-shelf but with numerous sub-tidal meanders and reversals. Drifters crossing the shelf edge between 55.4 and $56.1^{\circ} \mathrm{N}$ were recruited into the AIC. This behaviour is contrasted by the drifters which arrived on-shelf in December 2013. Both drifters crossed the shelf edge at $54.75^{\circ} \mathrm{N}$ and travelled in a northeasterly direction at speeds of $20-60 \mathrm{~cm} \mathrm{~s}^{-1}$. At $55.6^{\circ} \mathrm{N}$ they turned eastward and took very similar paths through the meridional line at $8^{\circ} \mathrm{W}$. Porter et al. (2018) inferred a cross-shelf transport of $0.2 \mathrm{~Sv}$ from the August drifter speeds using additional glider transects to estimate the cross-sectional area of the AIC core, where the AIC was defined as the region occupied by Eastern North Atlantic Water $\left(10-10.5^{\circ} \mathrm{C}, S>35.43\right)$. If we assume that the AIC occupied the same cross-sectional area during December, the peak drifter speeds of $60 \mathrm{~cm} \mathrm{~s}^{-1}$ observed in this study suggest that oceanic water import via the AIC may briefly reach $0.48 \mathrm{~Sv}$. This may be near the upper limit for the transport of oceanic water towards the coastline in the AIC based on the long-term salinity and current observations at the TPM.

To appraise the meteorological and oceanographic conditions on the shelf during the experiment, we compared the periods of drifter shelf transit with time series of reanalysis wind data on the Malin Shelf, the $20 \mathrm{~m}$ current speed at the TPM, and the $20 \mathrm{~m}$ salinity at the TPM (Fig. 5). Note that the TPM was undergoing maintenance during the early drifter experiment so TPM current speed and salinity data commence in late August 2013. The cross-shelf transit time of drifters in group 1 (August 2013) is between 18 and $42 \mathrm{~d}$. Wind forcing during this period is typical for the time of year at this location, with numerous short episodes of SW-NW winds of 10-15 $\mathrm{m} \mathrm{s}^{-1}$. In December 2013, however, three unusually strong westerly wind events occurred during a period dominated by westerly airflow. These were named Xaver (5-6 December), Bernd (18-19 December), and Dirk (2324 December). We can see from Fig. 2 that events of this magnitude typically occur once or twice per year during most winters. The onset of the first storm (storm Xaver) on 5 December 2013 (event A, Fig. 5) precedes an increase in along- 
(a) Deep drifters (August / September 2013)

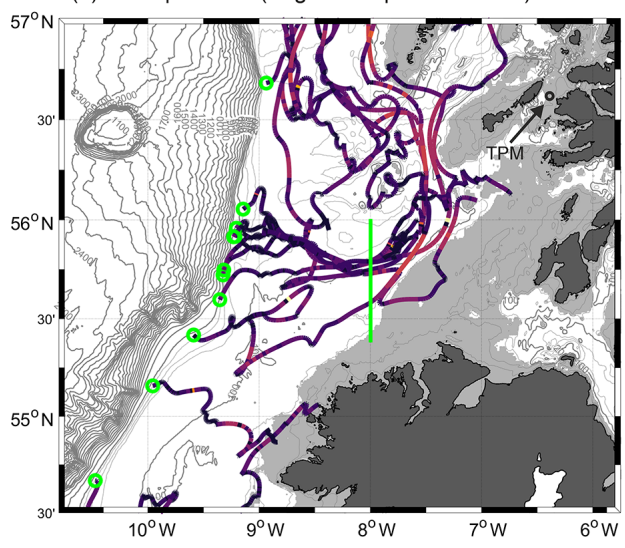

(b) Deep drifters (December 2013)

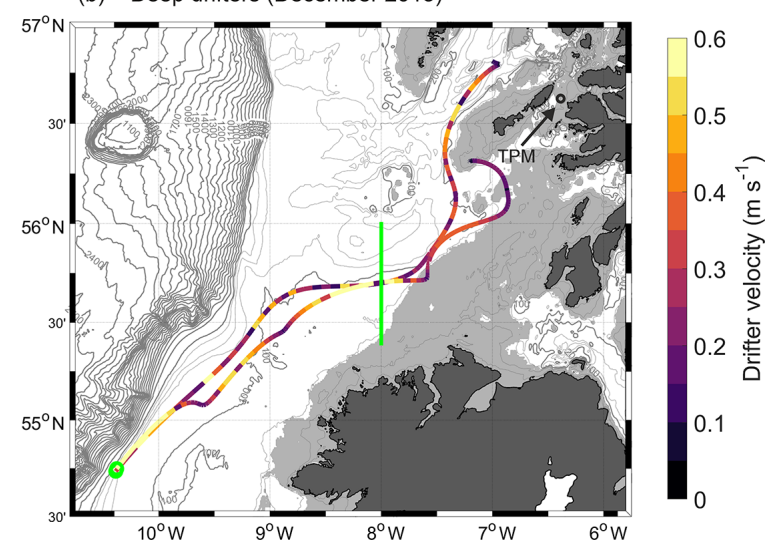

Figure 4. Trajectories of deep (drogued at $70 \mathrm{~m}$ ) drifters, coloured by velocity and separated into drifters which travelled on-shelf in (a) August-September 2013 and (b) December 2013. The tracks are set to commence when each drifter first crossed the $200 \mathrm{~m}$ isobath (beginning of each track indicated by green circles). The green line at $8^{\circ} \mathrm{W}$ indicates where drifters are deemed to have reached the inner shelf. The pale shaded region delineates the $70 \mathrm{~m}$ bathymetry. Bathymetry contours from GEBCO bathymetry (http://www.gebco.net/, last access: 24 July 2017).

channel currents at the TPM from $\sim 5 \mathrm{~cm} \mathrm{~s}^{-1}$ to greater than $30 \mathrm{~cm} \mathrm{~s}^{-1}$ to poleward (event B). Salinity at the TPM increases abruptly from 34.5 to 35 on 14 December 2013 (event C) and remains almost continually above 34.75 until 30 December 2013. The drifters transiting the shelf during this period do so in 6 and $10 \mathrm{~d}$, respectively.

\subsection{Modelled particle tracking}

The combination of drifter observations and the TPM salinity observations provides contrasting snapshots of cross-shelf flow during intense storms and a more quiescent period. However, the observations are in some ways not comparable: for example, when analysing the storm event, we compare the salinity at the TPM at $20 \mathrm{~m}$ of depth and the behaviour of drifters drogued at $70 \mathrm{~m}$ of depth which could not pass through Tiree Passage due to its shallow bathymetry. To present a more compelling picture of the periods under investigation, we supplement these observations with a series of particle-tracking experiments. Specifically, we seek to answer the following question: did the episode of stormy weather in December 2013 significantly alter the origins of water reaching the Scottish west coast throughout the water column? To address this question, we performed a series of particle-tracking experiments, focussing on particles terminating at the inner Malin Shelf. The particles were released at two depths: $20 \mathrm{~m}$ (the nominal depth of TPM observations) and $70 \mathrm{~m}$ (the drogue depth of the deep drifters) at the locations shown in Fig. 3a.

Figure 6 compares the tracks of particles terminating at the inner Malin Shelf during August 2013 (the first episode of on-shelf drifter advection) and during December 2013 when there was rapid on-shelf advection of two further drifters. Each cell is coloured by the percentage of particles released at that location which were subsequently advected through the observation region. In August, most particles at both 20 and $70 \mathrm{~m}$ originated within $50 \mathrm{~km}$ of the observation polygon, with a few cells west of $8^{\circ} \mathrm{W}$ featuring a particle contribution greater than $20 \%$. There is a small contribution from the North Channel of the Irish Sea at $20 \mathrm{~m}$, but this channel is closed to the $70 \mathrm{~m}$ particles by shallow bathymetry north of Ireland. The distribution of particles during the storm event (Fig. 6c and d) provides a contrasting picture, with up to $50 \%$ of particles released in some regions west of $8^{\circ} \mathrm{W}$ terminating in the observation polygon. At $20 \mathrm{~m}$ of depth, there is a clear preference for oceanic water reaching Tiree Passage, which is not present in the August experiment. The $70 \mathrm{~m}$ particles mostly originated from near the shelf edge at $55.5^{\circ} \mathrm{N}$ during the storm event. While a minority of $20 \mathrm{~m}$ particles originated off-shelf and crossed the shelf edge during the storm event, at $70 \mathrm{~m}$ all tracked particles remained on the northwest European shelf for the duration of the experiment.

A measure of typical particle advection times can be obtained by colouring particle origin cells by the average time their particles took to arrive at the observation polygons (Fig. 7). Note that Figs. 6 and 7 were produced using separate (but identical) batches of particle releases for computational reasons, with each batch consisting of five repeat experiments. Thus, the figures exhibit small differences in particle distribution due to the diffusive component of the particle motion. Again, the contrast between the $20 \mathrm{~m}$ particles in August and those in December highlights differences in the origins of the water. The source region of the December particles includes a broad section of the shelf edge, whereas in August the waters are sourced exclusively from the shelf. In addition, the December distributions indicate a relatively rapid pathway between the shelf edge at $55^{\circ} \mathrm{N}$ and the obser- 

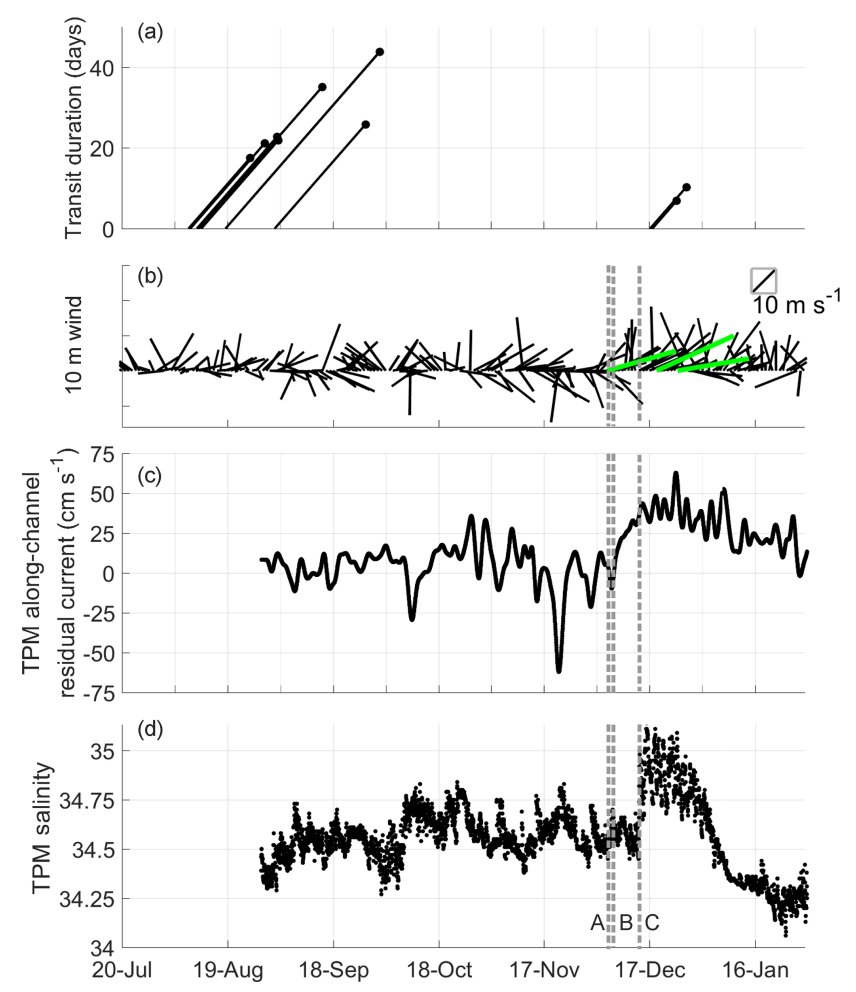

Figure 5. (a) Transit times and durations of $70 \mathrm{~m}$ drifters between the shelf edge ( $200 \mathrm{~m}$ isobath) and a meridional line at $8^{\circ} \mathrm{W}$ signifying arrival at the inner shelf. Lines commence as each drifter crosses the shelf edge and terminate when it passes $8^{\circ} \mathrm{W}$. (b) Vector plot of $10 \mathrm{~m}$ wind speed and direction on the Malin Shelf $\left(56^{\circ} \mathrm{N}, 7^{\circ} \mathrm{W}\right)$ derived from the ECMWF ERA-Interim product. Instances of westerly storm events (daily mean westerly wind $>18 \mathrm{~m} \mathrm{~s}^{-1}$ ) are shown in green. (c) Low-pass-filtered along-channel currents at the TPM and (d) $20 \mathrm{~m}$ salinity at the TPM. Grey dashed lines denote the following events. A: first storm event (storm Xaver). B: onset of strong poleward currents at the TPM. C: beginning of a high-salinity pulse (HSP) at the TPM.

vation polygons such that particles originating at this location can be expected to arrive at the coastline in 20-25 d.

\section{Discussion}

In this study we examined a period of intense shelf sea flows driven by a cluster of winter storms. The salinity and current speeds measured at the TPM during this event were amongst the highest measured by the mooring during its multi-year occupation. The spike in salinity at the TPM, coupled with the trajectories of two drogued drifters, confirmed that the origin of the water passing through Tiree Passage switched to the outer shelf during this period. In Sect. 4.1 we discuss the rapid (1-2d) increase in currents due to geostrophic flows driven by wind-induced pressure gradients on the northwest European shelf. This precedes the increase in salinity at the TPM by $8 \mathrm{~d}$, which we interpret as the time taken to advect high-salinity water from a remote location in the enhanced shelf currents. The nature of the high-salinity intrusion is discussed in Sect. 4.2. We then consider the additional insight provided by the particle tracking in Sect. 4.3 and the weather conditions associated with HSPs in Sect. 4.4. In Sect. 4.5 we investigate the likelihood of an HSP occurring in each winter.

\subsection{Dynamic response of the Malin Shelf to wind forcing}

There is strong evidence in the literature that wind-induced pressure gradients can quickly set up or enhance currents on the Malin Shelf and that their pathways are influenced by the wind direction (Davies and Xing, 2003; Inall et al., 2009; Jones, 2016; Xing and Davies, 2001). Similarly, the flow through the North Channel of the Irish Sea onto the Malin Shelf is highly correlated with wind aligned with the channel with a lag time of a few hours (Bowden and Hughes, 1961; Brown and Gmitrowicz, 1995). We may expect a rapid setup of inner shelf currents in response to a wind-induced surface pressure gradient as the barotropic adjustment time will be limited only by the speed of a long wave in shallow water. This speed is set by $\sqrt{g h} \approx 30 \mathrm{~m} \mathrm{~s}^{-1}$, which equates to a shelf-wide effect within a few hours. However, an abrupt onset of flow will be subject to inertial effects, so it may take 1 to $2 \mathrm{~d}$ for a stable flow to become established.

In addition to shelf-scale pressure gradients, winds with a westerly component will set up a local Ekman drift towards Northern Ireland. We would expect this flow to result in an elevated sea surface height and depressed isopycnals towards the northern Irish coast and in turn develop a geostrophic jet flowing eastwards along the northern Irish coast. Porter et al. (2018) noted depressed isopycnals associated with the core of the AIC during July 2013, so it is not unreasonable to surmise that Ekman effects act to enhance or complement the AIC.

If we consider the AIC and Tiree Passage to be subject to the same forcing influences, one might expect a link to exist between the speed of the drifters tracking the AIC and the poleward current speed concurrently measured at the TPM. However, we find little coherence between these measures (not shown), though both the drifters and the TPM do show increased current speed in December compared with $\mathrm{Au}$ gust. We surmise that the instantaneous sub-tidal speed of the drifters is a complex aggregate of wind-driven currents and local bathymetric flow intensification, so their speed does not correlate simply with that measured at the fixed mooring.

\subsection{Advection of salt tracer}

As a tracer of oceanic-origin water, the transport of salt is limited by the current speed on the shelf, and the $8 \mathrm{~d}$ lag between the increase in current speed and the onset of high salinity at the TPM points to the advection of the highsalinity water from a remote source. This lag period is in 
(a) 20 m depth; August

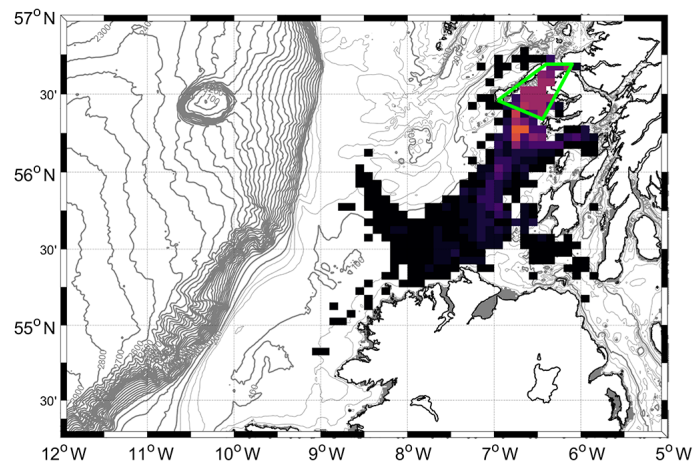

(c) $20 \mathrm{~m}$ depth; storm event

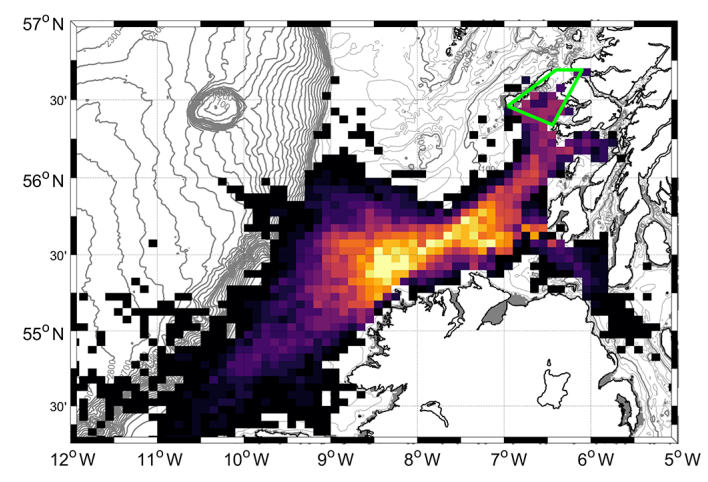

(b) $70 \mathrm{~m}$ depth; August

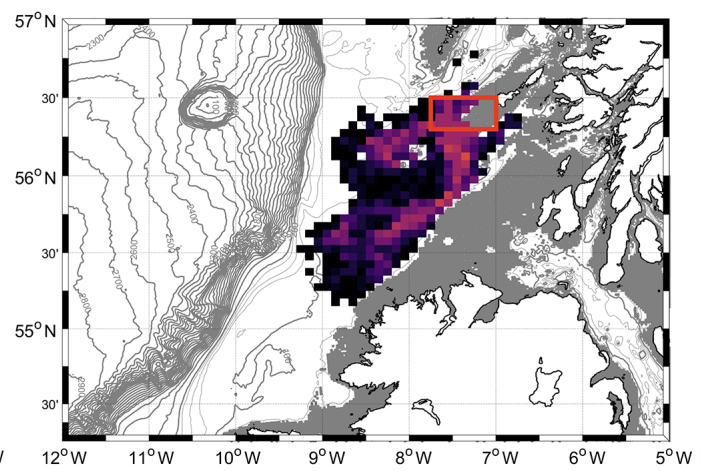

(d) $70 \mathrm{~m}$ depth; storm event

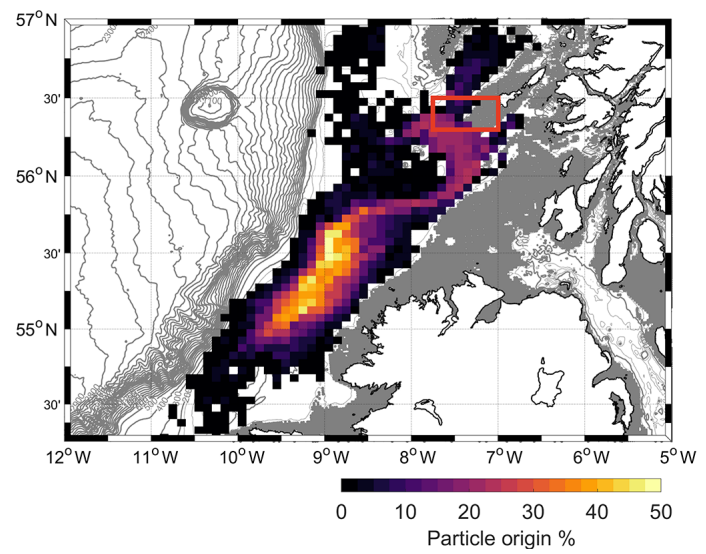

Figure 6. Particle distribution maps showing the origin of particles advected through Tiree Passage and the inner Malin Shelf. The green polygon shows the observation region for the $20 \mathrm{~m}$ particles in (a, c); for the $70 \mathrm{~m}$ particles in (b, d) the polygon (red) instead bisects the tracks of the drogued drifters as Tiree Passage is not open at this depth. Each cell is coloured by the percentage of particles released at that location which were subsequently advected through the observation region. The observation period for (a, b) is 1 to 11 August 2013 , and for (c, d) it is 15 to 25 December 2013. Note that these maps show particle release locations only and are not representative of model resolution. Bathymetry contours from EMODnet bathymetry (https://www.emodnet-bathymetry.eu/, last access: September 2015).

accord with the time taken by the December drifters to reach the inner shelf from the shelf edge (between 6 and $10 \mathrm{~d}$ ).

Integrating the TPM poleward current flow over the interval between the onset of enhanced flow (6 December 2013, event B) and the arrival of high-salinity water at the TPM (event C, 14 December 2013) gives a total displacement of $145 \mathrm{~km}$. If we assume this water arrived in Tiree Passage via the AIC, the minimum distance from the shelf edge to the TPM via this route is $210 \mathrm{~km}$, and the December drifters in fact crossed onto the shelf further south $\left(54.75^{\circ} \mathrm{N}\right.$, Fig. $\left.4 \mathrm{~b}\right)$, necessitating travel of at least $270 \mathrm{~km}$ to reach the TPM from the shelf edge at this location. It therefore seems likely that high-salinity water was already residing on the shelf prior to the first storm on 5 December 2013. The presence of nearoceanic water on the outer shelf is supported by observations of salinity distribution (Jones et al., 2018; Jones, 2016), radioisotopes tracking coastal water extent (McKay et al., 1986; McKinley et al., 1981), and distribution of other water properties such as temperature, chlorophyll, and nutrients on the shelf (Ellett, 1979; Ellett and Edwards, 1983; Siemering et al., 2016). In order to produce the observed lag at the TPM, we estimate that the high-salinity water originated at approximately $7.9^{\circ} \mathrm{W}$ at the latitude of the AIC, which is the location of maximum particle origin percentages in Fig. $6 \mathrm{c}$.

Unlike salinity, the temperature measured at the TPM (not shown) does not exhibit any notable deviation from the expected seasonal cooling at the time of the HSP investigated here. This is because there is very little difference between oceanic (near-surface) and coastal water temperatures on the Malin Shelf in December (Ellett and Edwards, 1983; Inall et al., 2009; Jones et al., 2018). A change in water origins from coastal to oceanic, however abrupt, would therefore have little impact on water temperatures at this time. However, between January and March coastal waters are cooler $\left(6-8^{\circ} \mathrm{C}\right)$ than the adjacent ocean $\left(9-10^{\circ} \mathrm{C}\right)$, so an HSP during this period would be likely to increase coastal water temperatures in western Scotland. We see some evidence of this effect in the 
(a) $20 \mathrm{~m}$ depth; August

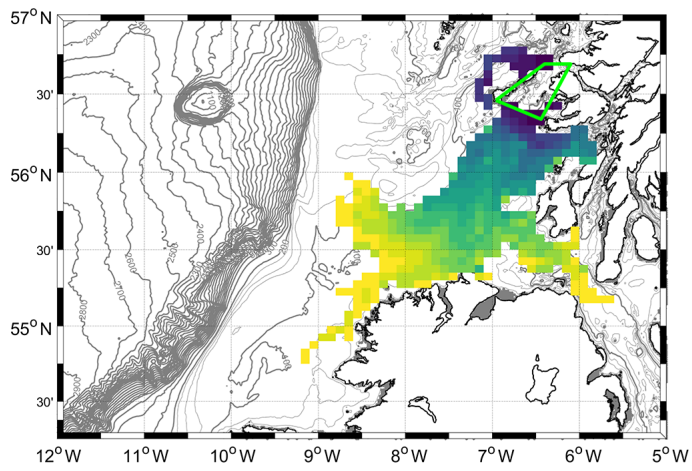

(c) $20 \mathrm{~m}$ depth; storm event

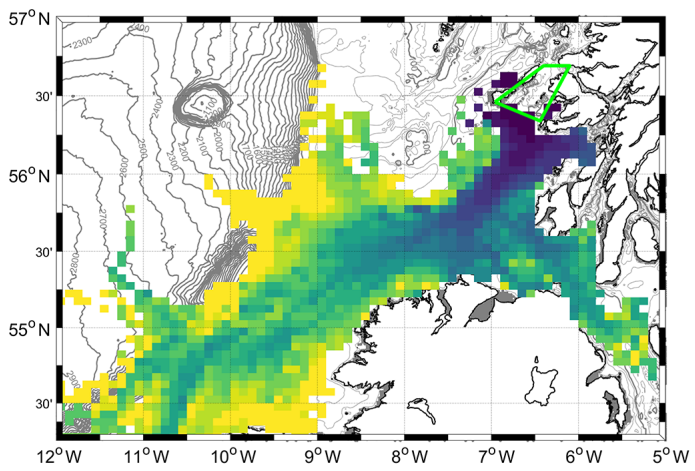

(b) $70 \mathrm{~m}$ depth; August

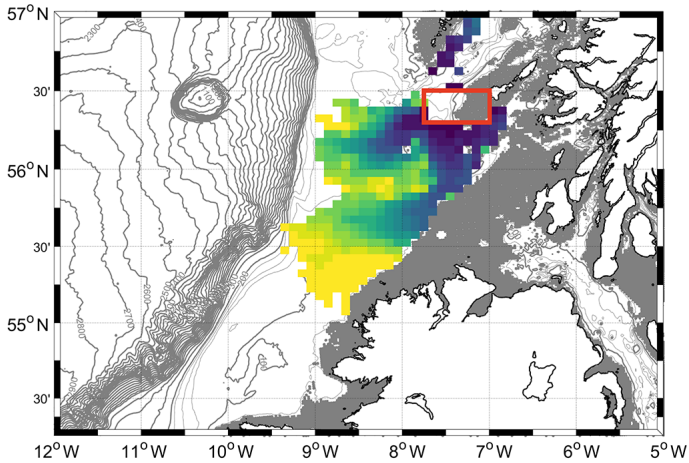

(d) $70 \mathrm{~m}$ depth; storm event

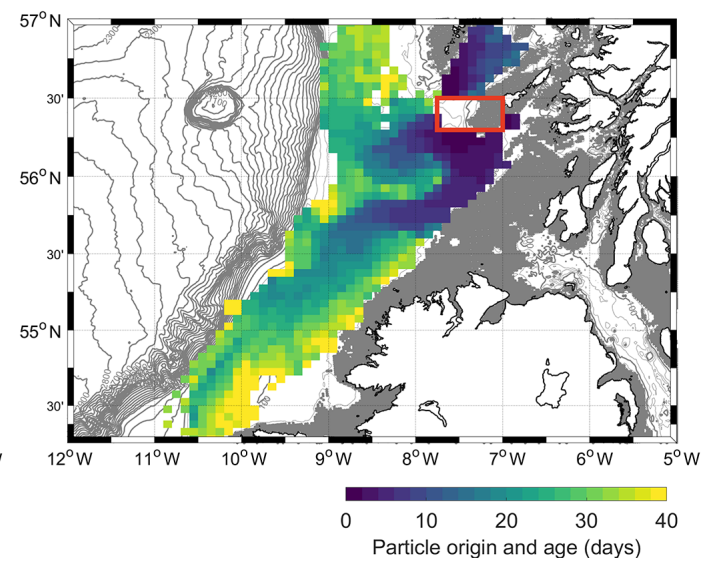

Figure 7. Particle distribution maps showing the origin of particles advected through Tiree Passage and the inner Malin Shelf. The green polygon shows the observation region for the $20 \mathrm{~m}$ particles in (a, c); for the $70 \mathrm{~m}$ particles in (b, d) the polygon (red) instead bisects the tracks of the drogued drifters as Tiree Passage is not open at this depth. Each cell is coloured by the average age of particles originating at this location, i.e. the number of days between the release of a particle and its arrival in the observation region. The observation period for (a, b) is 1 to 11 August 2013, and for (c, d) it is 15 to 25 December 2013. Note that these maps show particle release locations only and are not representative of model resolution. Bathymetry contours from EMODnet bathymetry (https://www.emodnet-bathymetry.eu/, last access: September 2015).

TPM temperature time series, with late-season HSPs sometimes associated with up to $0.5^{\circ} \mathrm{C}$ of warming.

Downstream of the TPM, coastal waters typically flow towards northwards towards the North Sea (McKay et al., 1986; McKinley et al., 1981). The Minch region between the islands of Skye and the Outer Hebrides represents a partial barrier to flow, so during the high transports associated with an HSP much of the imported water is likely to pass around the outside of the Outer Hebrides on the outer continental shelf. North of $58^{\circ} \mathrm{N}$, an average off-shelf transport occurs near the base of the water column into the Faroe-Shetland Channel (Graham et al., 2018b), so we surmise that a portion of the imported water makes its way back off-shelf via this region of the shelf edge, with the remainder continuing into the North Sea. It is notable that the drifters in this experiment all ultimately travelled into the North Sea (Fig. 1b), though their drogue depth prevented them from accessing the deep off-shelf flows predicted by Graham et al. (2018b).

\subsection{Particle release}

The model particle releases demonstrate a striking contrast between shelf behaviour in August 2013 and that during the storm event in December 2013. As might be expected from the evidence thus far, current speeds were slower in August and particles in the observation polygons originated more locally over the $50 \mathrm{~d}$ tracking period. This was true for both particles in the seasonal thermocline $(20 \mathrm{~m})$ and below it $(70 \mathrm{~m})$. By contrast, most particles tracked during the storm event originated between the mid-shelf and the shelf edge. The long transit time of the August particles would be associated with greater mixing between oceanic and shelf waters before reaching the coast. We would therefore expect that the high salinity associated with the inflow would be more dilute than during December. The preferential across-shelf pathway taken by most particles in Fig. 6d closely matches the route taken by the two drifters in Fig. 4b. This supports the notion 
(a)

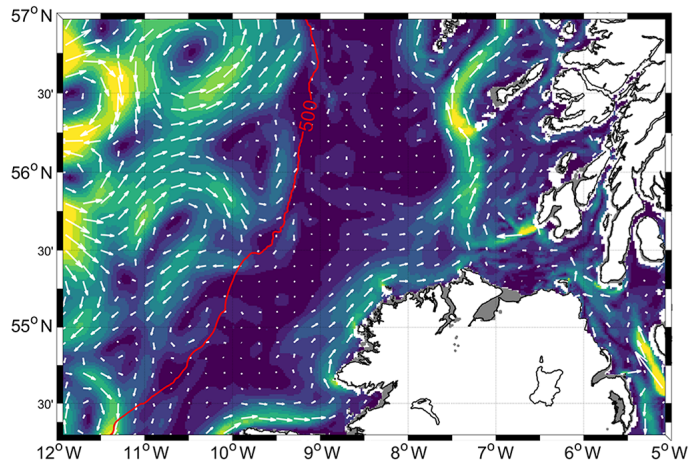

(c) $20 \mathrm{~m}$ depth; 15 to 25 December (storm event)

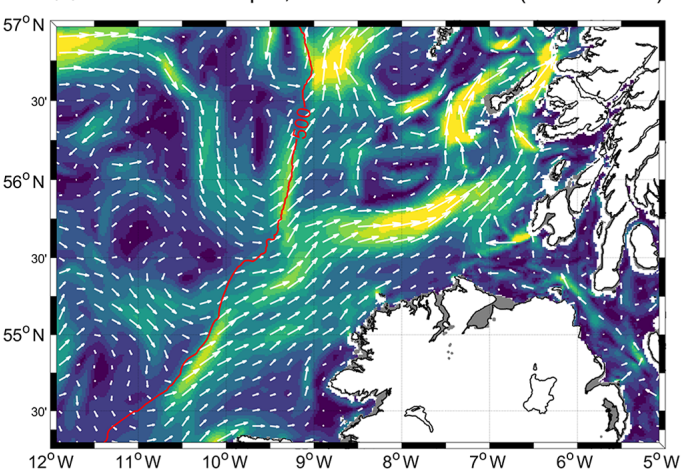

(b) $70 \mathrm{~m}$ depth; 1 to 11 August

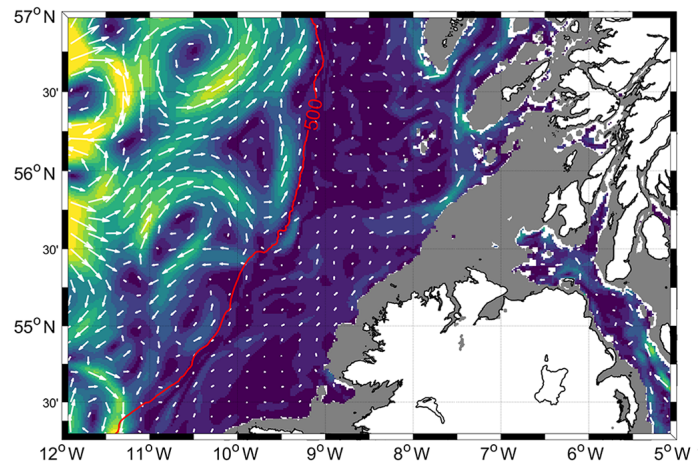

(d) $70 \mathrm{~m}$ depth; 15 to 25 December (storm event)

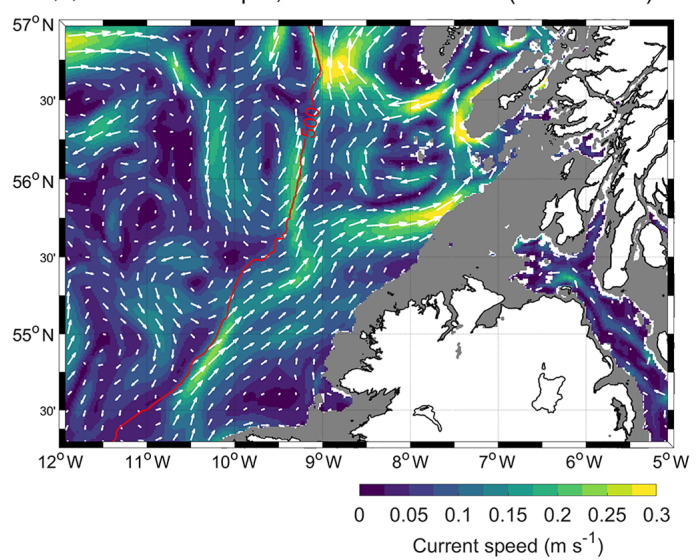

Figure 8. Average horizontal current velocity in the AMM15 model for (a) 1-11 August 2013 at 20 m of depth, (b) 1-11 August 2013 at $70 \mathrm{~m}$ of depth, (c) 15-25 December 2013 at $20 \mathrm{~m}$ of depth, and (d) 15-25 December 2013 at $70 \mathrm{~m}$ of depth. Bathymetry contour (red) from EMODnet bathymetry (https://www.emodnet-bathymetry.eu/, last access: September 2015).

of the AIC as a narrow, jet-like current, which was proposed by Porter et al. (2018). Further clarity on the modelled flow is obtained by comparing the average modelled current speed during the two $10 \mathrm{~d}$ observation periods (Fig. 8). The key difference between the August and December observation periods is the rapid across-shelf flow in December, which is not present during August. This disparity illustrates why most particle recruitment in August was restricted to the inner shelf: there was no pathway to enable transport from the shelf edge. In December, on-shelf flow exceeded $0.3 \mathrm{~m} \mathrm{~s}^{-1}$ in much of the AIC at $20 \mathrm{~m}$ of depth, and the pattern is similar, though slightly weaker, at $70 \mathrm{~m}$ of depth. The average salinity of particles within the observation region at $20 \mathrm{~m}$ was 34.26 during August and 34.81 in December. By comparison, at $70 \mathrm{~m}$ average particle salinity is slightly higher in August (35.30) than in December (35.27). The latter result may be because there is little influence of coastal water at $70 \mathrm{~m}$, so the basin west of Tiree is already occupied by older saline water.

Due to the design of the release and observation periods we might expect about one in five local releases to result in an observation in the polygons given steady flow. This is be- cause particles were released over a period of $50 \mathrm{~d}$ but were only tallied in the observation polygons for the final $10 \mathrm{~d}$ of the experiment (Fig. 3b), so the majority of local particles would pass through the observation polygon without being counted. However, in the December experiments we see high concentrations of particles originating remotely. This is a result of flow speeds increasing during the simulation, resulting in an effective convergence of particles during the observation period (days 40-50).

At the shelf edge, the insulating effect of the steep bathymetry maintains a strong control on ocean-shelf interaction for the model particles. There are almost no examples of $70 \mathrm{~m}$ particles crossing the shelf edge, and only a small proportion of $20 \mathrm{~m}$ particles crossed from ocean to shelf. Graham et al. (2018b) reported an on-shelf volume flux of roughly $5 \times 10^{4} \mathrm{~m}^{3} \mathrm{~s}^{-1}$ per $60 \mathrm{~km}$ shelf edge in this region, which is higher than most other sections of the European shelf edge. Given the evidence presented here for midshelf flows that are perhaps an order of magnitude greater during the stormy period, it is unsurprising that particles appear to be recruited from a broad swathe of the shelf edge before converging in the AIC. We find some preference for 

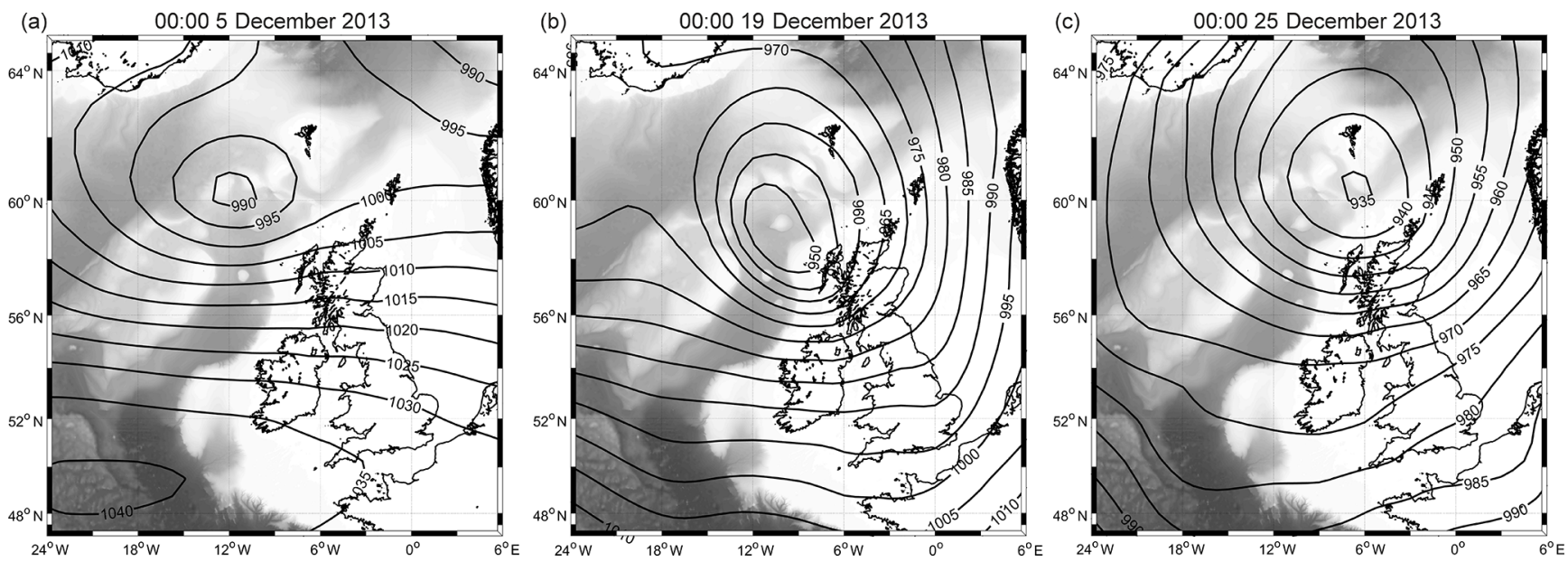

Figure 9. Sea level pressure maps for the three storm events associated with the winter 2013-2014 high-salinity pulse (HSP). These storms were named Xaver, Bernd, and Dirk, respectively. Sea level pressure data derived from the ECMWF ERA-Interim $0.75^{\circ} \times 0.75^{\circ}$ product. Bathymetry contours from GEBCO bathymetry (http://www.gebco.net/, last access: 24 July 2017).

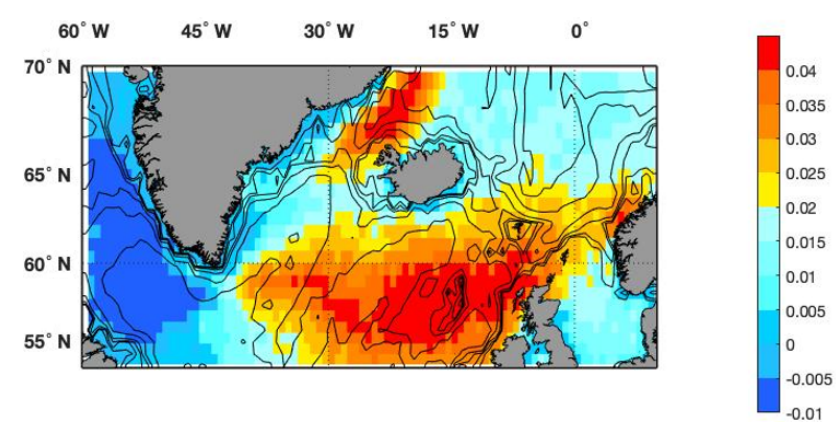

Figure 10. Mode 1 EOF winter (DJFM) gale days for North Atlantic. Based on ERA-Interim daily averaged $10 \mathrm{~m}$ wind speed and the WMO gale definition of wind speed exceeding $17.2 \mathrm{~ms}^{-1}$. Bathymetry contours from GEBCO bathymetry (http://www.gebco. net/, last access: 24 July 2017).

the recruitment of particles at the canyon systems around 55 and $55.5^{\circ} \mathrm{N}$ (Fig. 7), in agreement with the behaviour of the drogued drifters (Porter et al., 2018). These canyons appear to cause a breakdown in slope current stability, leading to greater cross-slope flow in their vicinity. For further examination of the implications of drifter trajectories on oceanshelf exchange in this region, see Burrows and Thorpe (1999) and Porter et al. (2018).

Graham et al. (2018b) found that cross-shelf fluxes in the surface layer $(0-20 \mathrm{~m})$ were larger during winter (January) than in the summer (July). The enhanced cross-slope flow during winter is likely to be due to increased wind forcing driving a downwelling circulation on the shelf, as described by Holt et al. (2009). The storm event depicted in the present study can be regarded as a snapshot of the processes contributing to the long-term winter average.

\subsection{Prerequisite weather conditions for a high-salinity pulse on the west coast of Scotland}

Given the regular passage of low-pressure systems across the UK during most winters, it is perhaps surprising that only one to two HSPs per year are recorded by the TPM. This finding indicates that further prerequisites are required to transport oceanic water to this inner shelf location. There is much evidence that the Malin Shelf is subject to an underlying baroclinic flow originating in the Irish Sea from tracers, oceanographic observations, and rotating tank experiments (Ellett, 1979; Ellett and Edwards, 1983; Hill, 1987; Jones et al., 2018; McKay et al., 1986; McKay and Baxter, 1985). Jones et al. (2018) conjectured that the relative infrequency of HSPs was because the inner shelf had a tendency to return to this baroclinic state in the absence of wind forcing. They argued that the displacement of water driven by a single lowpressure system may not be sufficient to advect oceanic water across the "buffer" of coastal waters which typically occupy the inner shelf. If we use, for example, the approximate linear relationship between wind and current speed in shallow seas suggested by Whitney and Garvine (2005),

$U_{\text {wind }} \approx 2.65 \times 10^{-2} U_{10}$,

where $U_{10}$ is the $10 \mathrm{~m}$ wind speed and $U_{\text {wind }}$ is the approximate developed wind-induced current flow, a fully developed current of $47 \mathrm{~cm} \mathrm{~s}^{-1}$ would be expected to result from a $24 \mathrm{~h}$ mean wind speed of $18 \mathrm{~m} \mathrm{~s}^{-1}$. This equates to a $24 \mathrm{~h}$ displacement of $\sim 40 \mathrm{~km}$, which is substantially less than the estimated $145 \mathrm{~km}$ travelled by the body of high-salinity water observed at the TPM. The additional factor prior to the December 2013 HSP may be that storm Xaver on the 5 December was followed by several days of strong southerly and westerly winds (e.g. Fig. 5b) which sustained the current system long enough for the outer shelf water to arrive in Tiree 


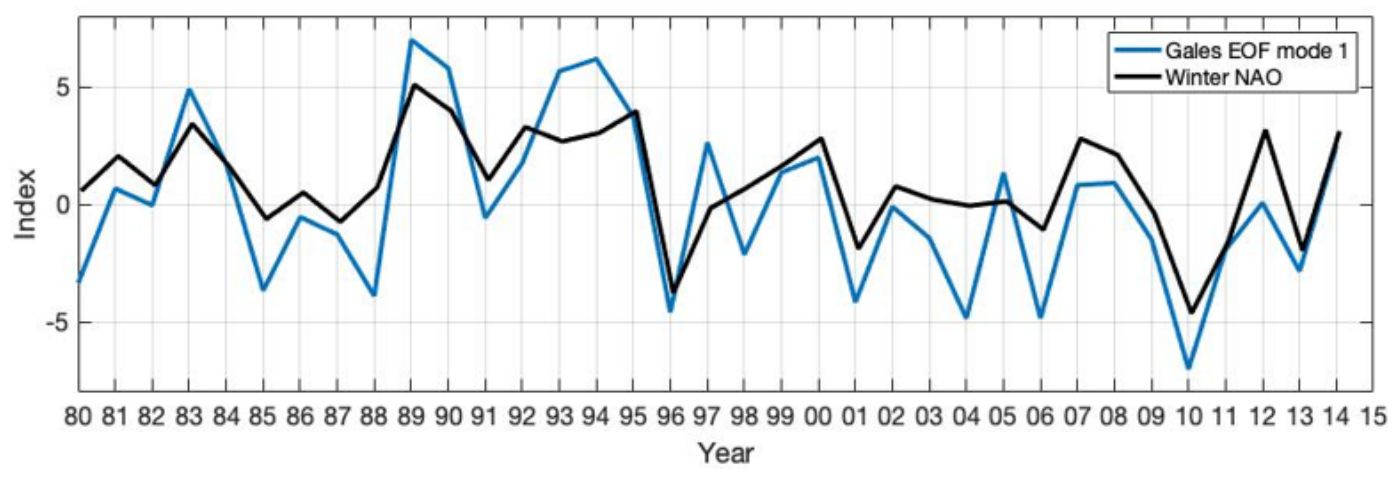

Figure 11. Time series (eigenvalues) of EOF mode 1 eigenvector pattern illustrated in Fig. 10 (blue line), defined as the North Atlantic gale index. NAO index after Hurrell (1995). The winter is defined as the year containing JFM; i.e. for a winter December 2013-March 2014, the year is 2014. The two indices correlate with $R=0.84$.

Passage $8 \mathrm{~d}$ later. The strong flow towards the coast and thus high coastal salinities were maintained throughout most of December 2013 by a pattern of low-pressure systems passing over Scotland. Jones et al. (2018) found surprisingly low correlations between southerly and westerly winds and the salinity measured at the TPM, and we suggest their finding was caused by this non-linear "pumping" of oceanic water to the inner shelf. We find no evidence of HSPs occurring outside the winter months (DJFM) and suggest this is due to a combination of reduced storm frequency and increased baroclinicity presenting more of a barrier to oceanic water ingress during the summer months. The trade-off between cumulative storm frequency, length scales, and baroclinic flow strength is likely to dictate the varying response to wind reported for other coastal current systems (e.g. Brooks and Townsend, 1989; Wiseman et al., 1997; Lentz et al., 2006).

Strong on-shelf flow towards the Scottish west coast only occurs during southerly to westerly winds, as other wind directions either drive Irish Sea water onto the shelf or retard shelf flow more generally (Davies and Xing, 2003; Jones et al., 2018). To illustrate the relevance of this note to the present study, sea level pressure maps of the major wind events associated with the December 2013 HSP are shown in Fig. 9. In each case an area of intense low pressure passed to the north of the UK, resulting in a westerly airflow over the Malin Shelf. The path of low-pressure systems over the northeastern Atlantic is captured by the North Atlantic Oscillation (NAO) index (Hurrell, 1995), which compares the atmospheric pressure over Iceland and the Azores. Positive NAO winters such as that of 2013-14 feature a northerly storm track, whereas during negative NAO years low-pressure systems tend to pass south of the UK. Consequently, conditions likely to result in an HSP episode are more likely to occur during positive NAO years. In the following section we explore the relationship between the NAO and storminess over the northeastern Atlantic.

\subsection{North Atlantic gale index and its relationship with the NAO}

We now analyse wintertime storminess over the North Atlantic by using daily $10 \mathrm{~m}$ wind speed data from the ERAInterim $0.75^{\circ} \times 0.75^{\circ}$ reanalysis product. Given this spatial and temporal resolution, peak wind speeds are likely to be underestimated, but the low-pressure systems of interest to this study (as illustrated in Fig. 9) are well resolved by the ERA-interim product. Furthermore, the AMM15 model used in the Lagrangian trajectory analyses was forced using ERAInterim data.

Following Qian and Saunders (2003) we define a set of wind speed indices as the numbers of days in each winter (DJFM) on which wind speeds exceed different force levels on the Beaufort wind scale and World Meteorological Organization (WMO) wind speed classification. These levels are near gale force (Beaufort scale 7, 13.9-17.1 ms ${ }^{-1}$ ), gale force (Beaufort scale 8, 17.2-20.7 $\mathrm{ms}^{-1}$ ), strong gale force (Beaufort scale 9, 20.8-24.4 $\mathrm{ms}^{-1}$ ), and storm force (Beaufort scale $10,24.5-28.4 \mathrm{~ms}^{-1}$ ). One "day" is counted for a particular grid cell and Beaufort scale level if the wind speed within that grid cell exceeds the lower limit of the particular scale level for that day. The total number of "days" is then accumulated for each grid cell, Beaufort scale level, and winter (DJFM) season. The winter is defined as the year containing JFM; i.e. for a winter December 2013-March 2014, the year is 2014.

Analysing the period 1979 to 2015, we perform an EOF decomposition of "gale force" winds over the whole North Atlantic (i.e. $17.2 \mathrm{~ms}^{-1}$, Beaufort scale 8 or greater). The first EOF mode (Fig. 10) captures $49 \%$ of the total variance. The mode 1 time series, which we define now as the gale index, significantly correlates with the winter NAO index over the same period, with $r=0.84$ (Fig. 11).

The mode 1 EOF pattern (Fig. 10) shows the storm track with a WSW to ENE orientation, as is typically associated with NAO-high winters. The most energetic landfall of this 
pattern is between 56 and $58^{\circ} \mathrm{N}$, broadly our region of interest. We note that during the winters of 2004, 2010, and 2013 no HSPs were recorded in the TPM record (Fig. 2), coinciding with a below-average gale index. In 2006 the gale index was also low, but no winter TPM data exist for that winter. 2004 and 2006 are interesting years because the gale index and NAO index exhibit differing behaviour in those years, suggesting the gale index may be a better predictor of shelf salinity conditions or HSPs than the NAO index, despite the very high correlation between the two indices $(r=0.84)$.

Between 1989 and 1994, Fig. 14 of Inall et al. (2009) shows a prolonged period of more saline shelf waters at $10 \mathrm{~m}$ of depth from Ellett Line CTD stations. This period corresponds to a high gale index period in the EOF mode 1 eigenvalue time series (Fig. 11). Further, the relative dip in the gale index in winter 1991 apparently coincides with a modest westward relaxation of isohaline contours, with fresher waters reappearing east of $6.5^{\circ} \mathrm{W}$. This 1989 to 1994 period precedes salinity measurements on the TPM, so we cannot comment on HSPs during this period of particularly stormy winters.

\section{Conclusions}

In this paper we have characterised an oceanic inflow onto the northwest European shelf during intense storm activity using drifters, a moored time series, and modelled particle tracking.

We found that during the storm event, across-shelf flow increased from 10-20 to $60 \mathrm{~cm} \mathrm{~s}^{-1}$, with a commensurate increase in estimated shoreward transport from 0.2 to $0.48 \mathrm{~Sv}$. Furthermore, we linked this unusually high import of oceanic water with an abrupt increase in salinity at the coastal mooring (from 34.5 to 34.85 in $24 \mathrm{~h}$ ), which occurred $8 \mathrm{~d}$ after the onset of storm activity. Given the lag time and the path of the drifters, we deduced that the coastal salinity spike was caused by the rapid import of water situated on the mid-shelf (at roughly $55.6^{\circ} \mathrm{N}, 7.9^{\circ} \mathrm{W}$ ) prior to the current intensification. Using modelled particle tracking, we showed that coastal water was preferentially recruited from the mid-to-outer shelf during the storm event, both at $20 \mathrm{~m}$ (the depth of the moored time series) and at $70 \mathrm{~m}$ (the depth of the drogued drifters). This contrasted with a more typical quiescent period in which coastal water was recruited locally over the experiment duration.

The spike in coastal salinity associated with storm activity was one of several in the 13-year mooring time series. To assess the likelihood of these sporadic storm episodes occurring during a given winter, we constructed a "gale index": a measure of the number of days wind speeds exceeded predefined thresholds across the North Atlantic. Despite high correlation between the gale index and the NAO index $(r=0.84)$, we found that the gale index may be a bet- ter predictor of salinity observed on the shelf than the NAO index.

Data availability. AMM15 model data are archived on the Met Office mass storage system and can be accessed through the STFCCEDA platform JASMIN (Lawrence et al., 2013). The NEMO code and the parameterisations used are outlined in Graham et al. (2018a). The drogued drifter data and Tiree Passage Mooring data are banked at the British Oceanographic Data Centre. Dataset information is available at https://edmed.seadatanet.org/ report/5930/ (Scottish Association for Marine Science, 2014) and https://edmed.seadatanet.org/report/5774/ (Scottish Association for Marine Science, 2016) respectively.

Author contributions. SJ prepared the paper with contributions from all co-authors. MI secured the funding for the work, developed the WMO gale index (Sec. 4.5), and made significant contributions to the particle-tracking experiment design. MP designed and executed the drogued drifter release experiment and helped to shape the present study. JG was a lead contributor to the design and testing of the AMM15 model and was instrumental in ensuring that the particle tracker was appropriately tuned for model diffusivity. FC helped to secure the funding for the work, provided mentorship in the form of $\mathrm{PhD}$ supervision to $\mathrm{SJ}$, and identified the relation between drifter behaviour and HSPs in the mooring salinity record.

Competing interests. The authors declare that they have no conflict of interest.

Acknowledgements. This study was funded by the UK Natural Environment Research Council (NERC) projects Fluxes Across Sloping Topography of the North East Atlantic (FASTNEt) (NE/I030151/1) and Overturning in the Subpolar North Atlantic Program (OSNAP) (NE/K010700/1). Marie Porter was supported by the AtlantOS project (European Union Horizon 2020 research and innovation programme, grant 633211). The authors would like to thank colleagues at the Met Office for their assistance in providing access to archived model output.

Financial support. This research has been supported by the UK Natural Environment Research Council (NERC) (grant nos. NE/I030151/1 and NE/K010700/1).

Review statement. This paper was edited by Erik van Sebille and reviewed by Robert Marsh and one anonymous referee.

\section{References}

Aleynik, D., Dale, A. C., Porter, M., and Davidson, K.: A high resolution hydrodynamic model system suitable for novel harmful algal bloom modelling in areas of com- 
plex coastline and topography, Harmful Algae, 53, 112-117, https://doi.org/10.1016/j.hal.2015.11.012, 2016.

Booth, D. A.: Eddies in the Rockall Trough, Oceanol. Acta, 11, 213-219, 1988.

Bowden, K. F. and Hughes, P.: The flow of water through the Irish Sea and its relation to wind, Geophys. J. Roy. Astr. S., 5, 265291, https://doi.org/10.1111/j.1365-246X.1961.tb00337.x, 1961.

Brooks, D. A. and Townsend, D. W.: Variability of the coastal current and nutrient pathways in the eastern Gulf of Maine, J. Mar. Res., 47, 303-321, https://doi.org/10.1357/002224089785076299, 1989.

Brown, J. and Gmitrowicz, E. M.: Observations of the transverse structure and dynamics of the low frequency flow through the North Channel of the Irish Sea, Cont. Shelf Res., 15, 1133-1156, https://doi.org/10.1016/0278-4343(94)00063-s, 1995.

Burrows, M. and Thorpe, S. A.: Drifter observations of the Hebrides slope current and nearby circulation patterns, Ann. Geophys., 17, 280-302, https://doi.org/10.1007/s00585-999-0280-5, 1999.

Davies, A. M. and Xing, J.: The influence of wind direction upon flow along the west coast of Britain and in the North Channel of the Irish Sea, J. Phys. Oceanogr., 33, 57-74, https://doi.org/10.1175/15200485(2003)033<0057:tiowdu>2.0.co;2, 2003.

Dee, D. P., Uppala, S. M., Simmons, A. J., Berrisford, P., Poli, P., Kobayashi, S., Andrae, U., Balmaseda, M. A., Balsamo, G., Bauer, P., Bechtold, P., Beljaars, A. C. M., van de Berg, L., Bidlot, J., Bormann, N., Delsol, C., Dragani, R., Fuentes, M., Geer, A. J., Haimberger, L., Healy, S. B., Hersbach, H., Hólm, E. V., Isaksen, L., Kållberg, P., Köhler, M., Matricardi, M., McNally, A. P., Monge-Sanz, B. M., Morcrette, J.-J., Park, B.-K., Peubey, C., de Rosnay, P., Tavolato, C., Thépaut, J.-N. and Vitart, F.: The ERA-Interim reanalysis: configuration and performance of the data assimilation system, Q. J. Roy. Meteor. Soc., 137, 553-597, https://doi.org/10.1002/qj.828, 2011.

Ellett, D. J.: Some oceanographic features of Hebridean waters, P. Roy. Soc. Edinb. B, 77, 61-74, https://doi.org/10.1017/S026972700001263X, 1979.

Ellett, D. J. and Edwards, A.: Oceanography and inshore hydrography of the Inner Hebrides, P. Roy. Soc. Edinb. B, 83, 143-160, 1983.

Ellett, D. J. and MacDougal, N.: Hydrographic conditions in the Rockall Channel and to the west of Scotland during 1982, Ann. Biol., 39, 38-40, 1985.

Gillibrand, P. and Willis, K.: Dispersal of sea louse larvae from salmon farms: modelling the influence of environmental conditions and larval behaviour, Aquat. Biol., 1, 63-75, https://doi.org/10.3354/ab00006, 2007.

Gowen, R. J., Raine, R., Dickey-Collas, M., and White, M.: Plankton distributions in relation to physical oceanographic features on the southern Malin Shelf, August 1996, ICES J. Mar. Sci., 55, 1095-1111, https://doi.org/10.1006/jmsc.1998.0418, 1998.

Graham, J. A., O’Dea, E., Holt, J., Polton, J., Hewitt, H. T., Furner, R., Guihou, K., Brereton, A., Arnold, A., Wakelin, S., Castillo Sanchez, J. M., and Mayorga Adame, C. G.: AMM15: a new high-resolution NEMO configuration for operational simulation of the European north-west shelf, Geosci. Model Dev., 11, 681696, https://doi.org/10.5194/gmd-11-681-2018, 2018 a.

Graham, J. A., Rosser, J. P., O’Dea, E., and Hewitt, H. T.: Resolving Shelf Break Exchange Around the European
Northwest Shelf, Geophys. Res. Lett., 45, 12386-12395, https://doi.org/10.1029/2018GL079399, 2018b.

Hill, A. E.: The Scottish Coastal Current in Spring 1982, MSc. Thesis, University of Bangor., 1983.

Hill, A. E.: The dynamics and variability of the Scottish coastal current, PhD. Thesis, Department of Physical Oceanography, 1987.

Hill, A. E. and Simpson, J. H.: Low-frequency variability of the Scottish coastal current induced by along-shore pressure gradients, Estuar. Coast. Shelf Sci., 27, 163-180, https://doi.org/10.1016/0272-7714(88)90088-1, 1988.

Holliday, N. P., Pollard, R. T., Read, J. F., and Leach, H.: Water mass properties and fluxes in the Rockall Trough, 1975-1998, DeepSea Res. Pt. I, 47, 1303-1332, https://doi.org/10.1016/s09670637(99)00109-0, 2000.

Holt, J. T., Wakelin, S. L., and Huthnance, J. M.: Down-welling circulation of the northwest European continental shelf: A driving mechanism for the continental shelf carbon pump, Geophys. Res Lett., 36, L14602, https://doi.org/10.1029/2009g1038997, 2009.

Hurrell, J. W.: Decadal trends in the North Atlantic Oscillation: regional temperatures and precipitation, Science, 269, 676-679, https://doi.org/10.1126/science.269.5224.676, 1995.

Huthnance, J. M., Holt, J. T., and Wakelin, S. L.: Deep ocean exchange with west-European shelf seas, Ocean Sci., 5, 621-634, https://doi.org/10.5194/os-5-621-2009, 2009.

Inall, M. E., Gillibrand, P. A., Griffiths, C., MacDougal, N., and Blackwell, K.: On the oceanographic variability of the NorthWest European Shelf to the West of Scotland, J. Mar. Syst., 77, 210-226, https://doi.org/10.1016/j.jmarsys.2007.12.012, 2009.

Jones, S., Cottier, F., Inall, M., and Griffiths, C.: Decadal variability on the Northwest European continental shelf, Prog. Oceanogr., 161, 131-151, https://doi.org/10.1016/j.pocean.2018.01.012, 2018.

Jones, S. C.: Shelf Edge Exchange and the Influence on Coastal Oceanography, PhD Thesis, University of Aberdeen, 2016.

Lawrence, B., Bennett, V., Churchill, J., Juckes, M., Kershaw, P., Pascoe, S., Pepler, S., Pritchard, M., and Stephens, A.: Storing and manipulating environmental big data with JASMIN, in: 2013 IEEE international conference on big data, 6-9 October 2013, Santa Clara, CA, USA, 68-75, IEEE, 2013.

Lentz, S. J., Largier, J., Lentz, S. J., and Largier, J.: The Influence of Wind Forcing on the Chesapeake Bay Buoyant Coastal Current, J. Phys. Oceanogr., 36, 1305-1316, https://doi.org/10.1175/JPO2909.1, 2006.

McKay, W. A. and Baxter, M. S.: Water transport from the North-east Irish Sea to western Scottish coastal waters: Further observations from time-trend matching of Sellafield radiocaesium, Estuar. Coast. Shelf Sci., 21, 471-480, https://doi.org/10.1016/0272-7714(85)90051-4, 1985.

McKay, W. A., Baxter, M. S., Ellett, D. J., and Meldrum, D. T.: Radiocaesium and circulation patterns west of Scotland, J. Environ. Radioactiv., 4, 205-232, https://doi.org/10.1016/0265931x(86)90011-1, 1986.

McKinley, I. G., Baxter, M. S., Ellett, D. J., and Jack, W.: Tracer applications of radiocaesium in the Sea of the Hebrides, Estuar. Coast. Shelf Sci., 13, 69-82, https://doi.org/10.1016/s03023524(81)80106-5, 1981.

Miller, R. G.: Larval dispersal and population connectivity: Implications for offshore renewable energy structures, $\mathrm{PhD}$ Thesis, University of Aberdeen, UK, 2013. 
Münchow, A. and Garvine, R. W.: Dynamical properties of a buoyancy-driven coastal current, J. Geophys. Res.-Oceans, 98, 20063-20077, 1993.

O'Dea, E., Furner, R., Wakelin, S., Siddorn, J., While, J., Sykes, P., King, R., Holt, J., and Hewitt, H.: The CO5 configuration of the $7 \mathrm{~km}$ Atlantic Margin Model: large-scale biases and sensitivity to forcing, physics options and vertical resolution, Geosci. Model Dev., 10, 2947-2969, https://doi.org/10.5194/gmd-102947-2017, 2017.

O'Dea, E. J., Arnold, A. K., Edwards, K. P., Furner, R., Hyder, P., Martin, M. J., Siddorn, J. R., Storkey, D., While, J., Holt, J. T., and Liu, H.: An operational ocean forecast system incorporating NEMO and SST data assimilation for the tidally driven European North-West shelf, J. Oper. Oceanogr., 5, 3-17, https://doi.org/10.1080/1755876X.2012.11020128, 2012.

Painter, S. C., Hartman, S. E., Kivimäe, C., Salt, L. A., Clargo, N. M., Bozec, Y., Daniels, C. J., Jones, S. C., Hemsley, V. S., Munns, L. R. and Allen, S. R.: Carbon exchange between a shelf sea and the ocean: The Hebrides Shelf, west of Scotland, J. Geophys. Res.-Oceans, 121, 4522-4544, https://doi.org/10.1002/2015JC011599, 2016.

Pingree, R. D., Sinha, B., and Griffiths, C. R.: Seasonality of the European slope current (Goban Spur) and ocean margin exchange, Cont. Shelf Res., 19, 929-975, 1999.

Porter, M., Dale, A. C., Jones, S., Siemering, B., and Inall, M. E.: Cross-slope flow in the Atlantic Inflow Current driven by the onshelf deflection of a slope current, Deep-Sea Res. Pt. I, 140, 173185, https://doi.org/10.1016/J.DSR.2018.09.002, 2018.

Proctor, R., Holt, J., Allen, J., and Blackford, J.: Nutrient fluxes and budgets for the North West European Shelf from a threedimensional model, Sci. Total Environ., 314-316, 769-785, https://doi.org/10.1016/S0048-9697(03)00083-4, 2003.

Qian, B. and Saunders, M. A.: Seasonal predictability of wintertime storminess over the North Atlantic, Geophys. Res. Lett., 30, 13, https://doi.org/10.1029/2003GL017401, 2003.

Reid, P. C., Holliday, N. P., and Smyth, T. J.: Pulses in the eastern margin current and warmer water off the north west European shelf linked to North Sea ecosystem changes, Mar. Ecol.-Prog. Ser., 215, 283-287, 2001.

Scottish Association for Marine Science: Fluxes Across Sloping Topography of the North East Atlantic (FASTNEt) Data Set, available at: https://edmed.seadatanet.org/report/5930/, last access: August 2014

Scottish Association for Marine Science: Time series data collected by the Tiree Passage current meter mooring (1981 onwards), available at: https://edmed.seadatanet.org/report/5774/, last access: January 2016.

Siddorn, J. R. and Furner, R.: An analytical stretching function that combines the best attributes of geopotential and terrain-following vertical coordinates, Ocean Model., 66, 1-13, https://doi.org/10.1016/J.OCEMOD.2013.02.001, 2013.
Siemering, B., Bresnan, E., Painter, S. C., Daniels, C. J., Inall, M., and Davidson, K.: Phytoplankton Distribution in Relation to Environmental Drivers on the North West European Shelf Sea, PLoS One, 11, e0164482, https://doi.org/10.1371/journal.pone.0164482, 2016.

Simpson, J. H. and Hill, A. E.: The Scottish Coastal Current, in The role of freshwater outflow in coastal marine ecosystems, 295308, Springer, 1986.

Simpson, J. H. and Sharples, J.: Introduction to the Physical and Biological Oceanography of Shelf Seas, Cambridge University Press, Cambridge, 2012.

Simpson, J. H., Edelsten, D. J., Edwards, A., Morris, N. C. G., and Tett, P. B.: The Islay front: Physical structure and phytoplankton distribution, Estuar. Coast. Mar. Sci., 9, 713-726, https://doi.org/10.1016/s0302-3524(79)80005-5, 1979.

Sybrandy, A. L., Niiler, P. P., Martin, C., Scuba, W., Charpentier, E., and Meldrum, D. T.: Global drifter programme barometer drifter design reference, DBCP Report 4, 2009.

Umlauf, L. and Burchard, H.: A generic length-scale equation for geophysical turbulence models, J. Mar. Res., 61, 235-265, https://doi.org/10.1357/002224003322005087, 2003.

van Sebille, E., Griffies, S. M., Abernathey, R., Adams, T. P., Berloff, P., Biastoch, A., Blanke, B., Chassignet, E. P., Cheng, Y., Cotter, C. J., Deleersnijder, E., Döös, K., Drake, H. F., Drijfhout, S., Gary, S. F., Heemink, A. W., Kjellsson, J., Koszalka, I. M., Lange, M., Lique, C., MacGilchrist, G. A., Marsh, R., Mayorga Adame, C. G., McAdam, R., Nencioli, F., Paris, C. B., Piggott, M. D., Polton, J. A., Rühs, S., Shah, S. H. A. M., Thomas, M. D., Wang, J., Wolfram, P. J., Zanna, L., and Zika, J. D.: Lagrangian ocean analysis: Fundamentals and practices, Ocean Model., 121, 49-75, https://doi.org/10.1016/j.ocemod.2017.11.008, 2018.

White, M. and Bowyer, P.: The shelf-edge current northwest of Ireland, Ann. Geophys., 15, 1076-1083, https://doi.org/10.1007/s00585-997-1076-0, 1997.

Whitney, M. M. and Garvine, R. W.: Wind influence on a coastal buoyant outflow, J. Geophys. Res.-Oceans, 110, C03014, https://doi.org/10.1029/2003JC002261, 2005.

Wiseman, W. J., Rabalais, N. N., Turner, R. E., Dinnel, S. P., and MacNaughton, A.: Seasonal and interannual variability within the Louisiana coastal current: stratification and hypoxia, J. Mar. Syst., 12, 237-248, https://doi.org/10.1016/S09247963(96)00100-5, 1997.

Xing, J. and Davies, A. M.: The influence of shelf edge flows and wind upon the circulation on the Malin Shelf and in the Irish Sea, Cont. Shelf Res., 21, 21-45, https://doi.org/10.1016/S02784343(00)00073-X, 2001.

Young, E. F. and Holt, J. T.: Prediction and analysis of long-term variability of temperature and salinity in the Irish Sea, J. Geophys. Res.-Oceans, 112, C01008, https://doi.org/10.1029/2005JC003386, 2007. 